FACTA UNIVERSITATIS

Series: Economics and Organization Vol. 15, Nº 3, 2018, pp. 279 - 293

https://doi.org/10.22190/FUEO1803279P

Preliminary Communication

\title{
THE INTERDEPENDENCE BETWEEN ENVIRONMENTAL AND SOCIAL PERFORMANCES AND COMPANY'S ECONOMIC VALUE: THE CASE STUDY OF TITAN CEMENT KOSJERIĆ
}

\author{
UDC 502/504:65.015.25 \\ 005.35
}

\section{Marija Petrović-Ranđelović, Tatjana Stevanović, Vesna Janković-Milić}

\author{
University of Niš, Faculty of Economics, Serbia
}

\begin{abstract}
The purpose of this paper is to research the relationship between environmental and social performances and company's economic value in case of the Titan Cement Kosjeric, and contribute to a clearer understanding of the importance of integrating the sustainable development principles into the business strategy and processes. The research was conducted using the data on selected financial and nonfinancial performances of the Company from the Reports on corporate social responsibility and sustainable development for the period from 2011 to 2015. To confirm the initial hypothesis, the method of analysis, method of synthesis, and the correlation analysis method were used. The empirical findings of this research indicate that there is a high degree of interdependence between environmental and social performance and Company's economic value, which is in line with the Company's commitment to sustainable development and socially responsible business. The main contribution of this paper is inhighlighting the importance of carrying out the socially responsible practices in the cement industry companies for improving all aspects of sustainable business - financial, environmental, and social.
\end{abstract}

Key words: sustainable development, environmental and social performances, company's economic value, Titan Cement Kosjerić

JEL Classification: F21, Q01, Q50, Q53

Received May 26, 2018 / Revised July 08, 2018 / Accepted July 12, 2018

Corresponding author: Marija Petrović-Ranđelović

Faculty of Economics Niš, Trg kralja Aleksandra 11, 18000 Niš, Serbia

E-mail: mrjpetrovic76@gmail.com 


\section{INTRODUCTION}

Contemporary technological development with intensive use of the environment as a source of inputs for the production process, direct recipients of negative production externals and space through which the distribution, use and disposal of manufactured products is made, has called into question the existence prerequisites for maintaining a healthy environment and limited the possibilities for sustainable development (adapted according: Hemmelskamp \& Leone, 2001). Furthemore, "climate changes and more frequent environmental degradation have influenced human awareness that their life and business style can seriously affect the quality of the environment" (Perović \& Radukić, 2017, p. 747), and that "the biological existence of a human depends on healthy environment, so the existence of the ever-lasting tendency for his survival is quite clear" (Magdalinović Kalinović \& Radukić, p. 428).

The impact of economic sectors on the state of the environment is uneven in time and in terms of intensity. One of the main pollution sources and generation of significant waste quantities is the industry sector. "However, all industrial branches do not have the same impact on the natural environment. This influence depends on the applied technique and technology characteristics, the type and origin of the obtained or processed raw materials in the technological processes of production" (Gligorijević \& Bošković, 2013, p. 350). Generally speaking, the industry sector environmental impact is reflected in the exhaustion of natural non-renewable resources, high energy consumption, soil, water and air pollution, climate change and global warming, acid rain and generating large quantities of harmful waste. However, "the role of industry and business in general in the achievement of sustainable development is beyond doubt, as demonstrated by emerging concepts such as responsible entrepreneurship and eco-efficiency and the capacity of enterprises to face new challenges such as globalization, the information society and the change of production and consumption patterns" (European Commission, 1999, p. 5).

The cement industry today distinguished itself as one environmentally sensitive industrial branch for several reasons.

First, cement production requires the consumption of a huge quantity of resources and energy. The cement industry is highly energy-intensive, since around $90 \%$ of the energy needed for cement production consists of thermal energy generated by direct fuel combustion in cement kilns.

Second, with the rise of the world's population, demand for energy and construction materials is constantly increasing, which has an impact on the increase in greenhouse gas emissions. The cement industry participates with around 5\% in the total broadcasted quantity at the global level.

Third and associated with the previous, increased global warming caused by carbon dioxide $\left(\mathrm{CO}_{2}\right)$ emissions causes climate change with multiple negative economic, environmental and social impacts globally.

Besides the introductory considerations, this paper consists of the following parts: In the second part of the paper the attention is devoted to the importance of integration, environmental and social components in the company's management system, with particular focus on sustainable development concept application in the cement industry. The third part of the paper provides an insight into the research methodology and initial research hypothesis. The research results and their discussion are given in the fourth part of the paper. Finally, concluding observations are made in the last part of the paper. 


\section{RESEARCH CONTEXT}

\subsection{Integration of environmental and social components into the company's management system}

The concept of sustainable development is presented with a model of three pillars that consist of economic, environmental and social. The economic pillar indicates the need to ensure the well-being of people through the efficient use of natural resources. The social pillar of sustainable development is a requirement for social services to be more accessible to people, including several different dimensions: provision of educational services, access to health services, the provision of acceptable living standards and employment, and so on. The environmental pillar of sustainable development implies conservation and preservation of the physical and biological bases of the ecosystem (adapted according to: Jovanović et al., 2011, p. 49-50).

\begin{tabular}{|l|l|}
\hline \multicolumn{2}{|c|}{ Environmental exposure } \\
\hline Type of environmental intervention & Activities specific to the enterprise \\
\hline Emissions (in air, water and land) & $\ldots$ \\
Waste & $\ldots$ \\
Material inputs / material intensity & $\ldots$ \\
Energy intensity & $\ldots$ \\
Noise and vibration & $\ldots$ \\
Thermal energy loss & $\ldots$ \\
Radiation & $\ldots$ \\
Direct interventions in nature & $\ldots$ \\
\hline
\end{tabular}

Fig. 1 A framework for identifying the environmental exposure of companies Source: Figge, F., Hahn, T., Schaltegger, S. \& Wagner, M. (2002). The sustainability balanced scorecard - Linking sustainability management to business strategy. Business Strategy and the Environment, 11(5), 269-284, p. 277.

Identification of exposure to the environmental and social dimension, both at the level of the business unit and at the company level, is a necessary step in defining the management system for long-term business strategy management. As a result of these efforts, the profile of environmental and social exposure is identified, for the purpose of identifying all relevant environmental and social aspects. There are two frameworks that are used to identify the degree of environmental and social exposure of companies. The first framework represents the company's environmental exposure, and the main idea is to display environmental interventions that arise from company-specific operations. The environmental exposure is shown in Figure 1.

Strategically relevant social aspects can be identified in line with environmental aspects. However, given the large number of differences in social aspects and the lack of foundation in natural sciences, it is difficult to achieve their comprehensive classification. It is important to note that the social aspect mostly depends on the preferences and values of the different subjects who act on the business scene. It is recommended that the classification of social factors is carried out by the actors involved, not by their content. 
The stakeholder approach provides a quality and useful basis for the classification of actors of different social requirements. Figure 2 shows a classification according to the previous criteria.

The social aspect can be identified systematically, following a comprehensive framework of potentially relevant stakeholder groups. These stakeholders can be divided into: internal stakeholders, stakeholders from the value chain, stakeholders from the local community and social stakeholders. Stakeholders can be classified into two groups - direct and indirect. The direct group includes stakeholders who connect with a company through direct exchange of material resources, while with indirect stakeholders there is no such type of exchange. In the first step, all relevant stakeholder groups need to be identified. It is then necessary to determine the social requirements and issues raised by those groups.

\begin{tabular}{|c|c|c|c|c|c|c|c|}
\hline \multicolumn{8}{|c|}{ Social exposure } \\
\hline \multicolumn{4}{|c|}{ Direct stakeholders } & \multicolumn{4}{|c|}{ Indirect stakeholders } \\
\hline Internal & $\begin{array}{c}\text { From the } \\
\text { value chain }\end{array}$ & $\begin{array}{c}\text { From the } \\
\text { local } \\
\text { community }\end{array}$ & Social & Internal & $\begin{array}{c}\text { From the } \\
\text { value chain }\end{array}$ & $\begin{array}{c}\text { From the } \\
\text { local } \\
\text { community }\end{array}$ & Social \\
\hline $\begin{array}{l}\text { Special } \\
\text { groups of } \\
\text { stakehold. } \\
\ldots \\
\text { requests / } \\
\text { questions } \\
\ldots\end{array}$ & $\begin{array}{l}\text { Special } \\
\text { groups of } \\
\text { stakehold. } \\
\ldots \\
\text { requests / } \\
\text { questions } \\
\ldots\end{array}$ & $\begin{array}{l}\text { Special } \\
\text { groups of } \\
\text { stakehold. } \\
\ldots \\
\text { requests / } \\
\text { questions } \\
\ldots\end{array}$ & $\begin{array}{l}\text { Special } \\
\text { groups of } \\
\text { stakehold. } \\
\ldots \\
\text { requests / } \\
\text { questions } \\
\ldots\end{array}$ & $\begin{array}{l}\text { Special } \\
\text { groups of } \\
\text { stakehold. } \\
\ldots \\
\text { requests / } \\
\text { questions } \\
\ldots\end{array}$ & $\begin{array}{l}\text { Special } \\
\text { groups of } \\
\text { stakehold. } \\
\ldots \\
\text { requests / } \\
\text { questions } \\
\ldots\end{array}$ & $\begin{array}{l}\text { Special } \\
\text { groups of } \\
\text { stakehold. } \\
\ldots \\
\text { requests / } \\
\text { questions } \\
\ldots\end{array}$ & $\begin{array}{l}\text { Special } \\
\text { groups of } \\
\text { stakehold. } \\
\ldots \\
\text { requests / } \\
\text { questions } \\
\ldots\end{array}$ \\
\hline
\end{tabular}

Fig. 2 A framework for identifying the social exposure of companies Source: Figge, F., Hahn, T., Schaltegger, S. \& Wagner, M. (2002). The sustainability balanced scorecard - Linking sustainability management to business strategy. Business Strategy and the Environment, 11(5), 269-284, p. 278.

Determining strategical relevant aspects is a key step both in the classical and in the new, expanded concept of the control system. The basic purpose of such step is to translate a formulated strategy into cause-and-effect related goals and indicators. It is necessary to repeat Kaplan and Norton's (1992) recommends that the process of identifying strategically relevant aspects is realized on the top-down principle, i.e. that all major initiatives, proposals and solutions go from top management. Of course, the same approach, which is valid in the traditional concept, can also be applied to the sustainable development management system. The only difference is that, in addition to standard perspectives, environmental and social considerations are taken into account. It should be noted that the hierarchical and causal link is guaranteed so that it will serve to unify all strategically important aspects in the direction of the successful conversion of the strategy and its direction towards long-term development.

There are three levels of the environmental and social component strategic relevance in the literature and they are presented in the following way (Figge et al., 2002, p. 279):

1) Environmental and social components can be strategic key items for which the so called, consequential indicators must be identified. Their basic role is to measure whether strategic and substantive requirements are achieved in perspective. 
2) Key performance measures, presented by leading indicators, show how to achieve results in each perspective, which are reflected in subsequent indicators. Leading indicators have a high level of business specificity and will reflect environmental and social aspects in every situation in which they act as key performance benchmarks.

3) Environmental and social aspects can also be represented by the so-called, clean (hygienic) factors that can best be seen through diagnostic indicators. Clean factors are items that need to be managed sufficiently to ensure the successful execution of business operations, but the inclusion of these factors does not contribute to any comparative advantage. Simply, hygienic factors represent a necessary but not sufficient condition for successful implementation of the company strategy. For this reason, these factors are not included in the BSC concept.

\begin{tabular}{|c|c|c|c|c|c|c|c|c|c|c|c|c|c|c|c|c|}
\hline & \multirow{2}{*}{\multicolumn{8}{|c|}{ Environmental exposure }} & \multicolumn{8}{|c|}{ Social exposure } \\
\hline & & & & & & & & & \multicolumn{4}{|c|}{ Direct stakeholders } & \multicolumn{4}{|c|}{$\begin{array}{c}\text { Indirect } \\
\text { stakeholders }\end{array}$} \\
\hline & 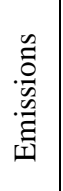 & $\frac{0}{5}$ & 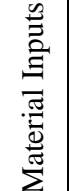 & 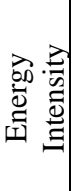 & 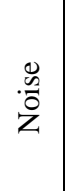 & 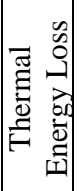 & 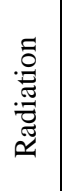 & 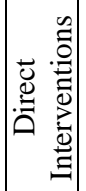 & 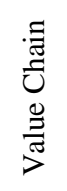 & 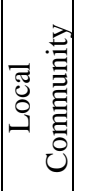 & 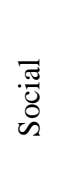 & 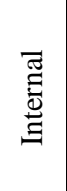 & 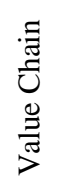 & 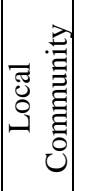 & $\begin{array}{l}\cdot \overrightarrow{\frac{\pi}{0}} \\
\overline{0} \\
\bar{n}\end{array}$ & $\begin{array}{l}\bar{\sigma} \\
\overline{0} \\
0 \\
\text { in }\end{array}$ \\
\hline 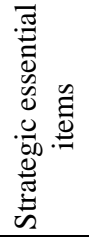 & & & & & & & & & & & & & & & & \\
\hline 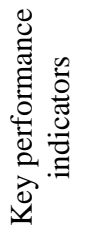 & & & & & & & & & & & & & & & & \\
\hline
\end{tabular}

Fig. 3 Matrix for determining the strategic relevance of the environmental and social component

Source: Figge, F., Hahn, T., Schaltegger, S. \& Wagner, M. (2002). The sustainability balanced scorecard - Linking sustainability management to business strategy. Business Strategy and the Environment, 11(5), 269-284, p. 279.

It is necessary to emphasize the strategic importance of the environmental and social component and to determine whether they represent strategic key items, key performance metrics or pure factors. For this reason, a matrix that will interconnect one with another, environmental and social exposure, and on the other hand, the category of leading and consequential indicators is shown in Figure 3. 


\subsection{Application of the sustainable development concept in the cement industry}

Many companies operating in the cement industry are today faced with numerous challenges in all three sustainable development dimensions. Within the economic dimension, the key issue is to ensure the financial prosperity of the company and all its stakeholders, since creating enterprise value for cement companies is linked to their ability to address external stakeholder issues. Within the social dimension, they are faced with problems related to the cement production impact on human well-being and satisfying the employees' needs and the society as a whole. Problems in the domain of environmental dimensions require the use of exante and ex-post activities in order to ensure the overall environmental favorable business of the company. These include addressing issues related to resource extraction and their impact on environmental quality; using non-renewable resources; quarrying, cement production, dust transport emissions; the air emissions (such as emissions of $\mathrm{NO}_{\mathrm{x}}, \mathrm{SO}_{2}, \mathrm{CO}$, etc.), and also $\mathrm{CO}_{2}$ emissions that cause global climate change.

Companies operating in this environmentally sensitive industry have found that in order to remain competitive they must combine sound financial performance with an environmental responsibility commitment, and open and honest interaction with stakeholders (World Business Council for Sustainable Development, 2002). They today bear great responsibility for achieving sustainable development, applying such policies that contribute to the achievement of continuous economic growth without causing damage to the environment and exploitation of the workforce by respecting key labor standards. The key factors that contributed to the increase of the cement companies' environmental responsibility include:

- The need to increase resource efficiency, reduce operating costs through waste reduction, recycling and secondary use of waste.

- The pressure of key stakeholders towards greening the business.

- Customers' demands and needs in terms of using environmentally preferable cement plant products.

- Local communities' environmental concerns in terms of cement production externalities.

- Stronger environmental regulations of the host country and home country governments.

- Innovations towards introducing new environmental technologies and production processes.

- Increasing demand for global accountability and transparency of company's activities.

In addition to the aforementioned so-called push factors there are also certain limiting factors that hinder the efforts of cement companies to implement the sustainable development concept. These include the following:

- Inability to change product characteristics or manufacturing process.

- High resource and capital intensity that limits the ability for faster changes in the production process.

- Product standards designed to provide safety and integrity of built structures limit product innovation.

- Market demand in the direction of use and higher strength cement lead to faster resource depletion.

- Relatively uniform price of cement industry products across companies makes it difficult to take investments in sustainable business practices. 
In April 2002, the cement factory in Kosjerić became a part of Titan Group, a renowned cement and building materials producer that operates in 36 countries, employs approximately 5.500 workers worldwide and has a business tradition longer than 11 decades (adapted according: Titan Group, 2018). The acquisition of a factory by one of the largest construction material manufacturers in the world has opened a new chapter in the social business responsibility and cement factory development for several reasons.

First, the Titan Group since the establishment and commissioning of the first cement plant in Greece in 1902 follows the principles of corporate social responsibility. The social dimension of business was confirmed already in 1922 when the Company insured employees in the event of an injury at work, providing numerous benefits to employees and assisting the vulnerable population in situations of natural disasters and during the Second World War. The Company implemented its first environmental activities by introducing the first electrostatic filter at the plant in Greece in 1960. The Company's commitment to the implementation of corporate social responsibility is confirmed by the fact that as a leader in this field and in order to ensure transparency of its activities, it published the first Annual Social Report, entitled Social Balance, in 1983.

Second, Titan Cement Kosjeric is a good example of a company that is - due to the efforts to the achievement of sustainable development principles - gaining a reputation of an environmentally and socially responsible company. The philosophy of sustainable development is a permanent commitment of the Company, and long-term results of this commitment are reflected through investments in manufacturing technology, the implementation of various projects in the fields of environment, education, health and safety at work, the local community and its immediate surroundings (addapted according: Titan Cementara Kosjerić, 2018a).

Third, the corporate social responsibility policy adopted in 2010 determines corporate social responsibility in line with the corporate vision. Also, in order to increase the transparency of activities and to maintain the reputation of an environmentally conscientious investor, in 2011 Titan Cement Kosjerić issued its first annual report on corporate social responsibility and sustainable development.

Fourth, "commitment of Titan Group to corporate social responsibility and sustainable development is confirmed through business policies and practices and through active participation in international initiatives" (Titan Cementara Kosjerić, 2018b). As a first Greek signatory company to the UN Global Compact, Titan strives to ensure the human and labor rights protection, environmental protection, and to fight against bribery and corruption. Also, Titan is a member of CSR Europe, the WBCSD Initiative for sustainability in the cement industry and the European Alliance for CSR.

Fifth, Titan Cement Kosjeric is the first company in the Republic of Serbia, which submitted in March 2010 complete documentation for publishing the integrated permit to the Ministry of Environment and Spatial Planning. In line with the Law on integrated prevention and environmental pollution control, the company receives an integrated permit (IPPC) in June 2011.

Sixth, the Company undertakes proactive activities on identifying and managing risks and opportunities in order to track future business guidelines in a competitive and rapidly changing global market. Within the identified risks, climate change takes a special place. The Company's strategic reaction to climate change is reflected on steering the efforts to find the best available technologies, increasing the use of alternative raw materials and 
fuel, and improving energy efficiency. Such strategic orientation is confirmed by adopting the Strategy for mitigating climate change in 2006, with which is harmonized business imperative, contained in the task that in the production process makes less bad, while ensuring that it makes more good.

\section{RESEARCH METHODOLOGY AND HYPOTHESIS}

The Titan Cement Kosjerić Company is committed to improving environmental performances, promoting socially responsible business towards the main challenges of the $21^{\text {st }}$ century. The key activities with which the Company confirms concerns for future generations and maintains the reputation of an environmentally responsible company relates to reducing air emissions and impact on climate change, reducing water and fossil fuel consumption, conserving biodiversity, and managing waste. These target-oriented activities ensure the compatibility between the strategic business objectives and the sustainable development principles and contribute to company's operational efficiency. Titan Cement Kosjerić applies high business standards and adheres to valid regulations, which further confirms its responsible attitude towards the environment and serves as an example of best practice of responsible business for other companies.

The key institutional support for sustainable environmental management in the Company provides the environmental management system, which establishes, promotes and reviews the Company's contribution in this field. In addition, the Company's commitment to preserving natural resources can be identified by providing financial support in the implementation of research programs and improving the technological basis of production, as well as by raising the employees' awareness, as well as all relevant actors in the value chain.

In addition to the environmental dimension, an important dimension of the Company's sustainable business makes the Company's commitment to continuous improvement of the employees' quality by organizing various training programs and seminars, and learning through work. In particular, the Company contributes to the development and expansion of a security culture through theoretical education and practical operational training for the safe execution of all operations.

The quantification of the efforts that Titan Cement Kosjerić makes in the direction of improving the environmental and social performances is the subject of the research that is covered in this paper. The basic hypotheses from which the research begins are as follows:

H1: The Company's results are related to defined targets in reducing greenhouse gas emissions and packaging waste management by 2020 .

H2: There is direct interdependence between the Company's economic value and the social performances.

In confirming the above laid hypotheses, the method of analysis, method of synthesis, and the correlation analysis method were used, that is, the specificcalculation of nonparametric quantitative agreement indicators (Spearman's coefficient of correlation of ranks). Research is conducted using the data on selected financial and nonfinancial performances from the available Titan Cement Kosjerić Reports on corporate social responsibility and sustainable development for the period from 2011 to 2015 (see Table 1). 
Table 1 Selected financial and nonfinancial indicators of business performances, Titan Cement Kosjerić, 2011-2015

\begin{tabular}{|c|c|c|c|c|c|}
\hline & 2011 & 2012 & 2013 & 2014 & 2015 \\
\hline \multicolumn{6}{|l|}{ Selected financial indicators } \\
\hline Total cement production & 517,456 & 442,201 & 364,849 & 380,272 & 410,115 \\
\hline Net profit (after income taxes $(000 €)$ & 13,257 & 15,869 & 8,439 & 8,993 & 8,065 \\
\hline $\begin{array}{l}\text { Increase of the company's economic } \\
\text { value }(000 €)\end{array}$ & 15,354 & 12,518 & 9,766 & 10,175 & 9,807 \\
\hline \multicolumn{6}{|l|}{ Selected nonfinancial indicators } \\
\hline Natural raw materials consumption $(\mathrm{t})$ & 649,349 & $617,695.5$ & $468,191.7$ & 466,429 & $514,503.01$ \\
\hline $\begin{array}{l}\text { Secondary raw materials share in the } \\
\text { consumption of materials }\end{array}$ & $13.98 \%$ & $9.8 \%$ & $10.2 \%$ & $15.2 \%$ & 11.53 \\
\hline Total direct $\mathrm{CO}_{2}$ emissions $\left(\mathrm{kg} / \mathrm{t}_{\text {product }}\right)$ & 623 & 650 & 623 & 615 & 605 \\
\hline \multicolumn{6}{|l|}{ Air emissions } \\
\hline Particulate matters total emissions (t) & 1.8 & 1.55 & 1.05 & 1.08 & 1.14 \\
\hline $\mathrm{NO}_{\mathrm{x}}$ total emissions $(\mathrm{t})$ & 428 & 461.75 & 296.9 & 329.4 & 262.3 \\
\hline Recycled waste quantity (t) & - & 83.74 & 166.58 & 417.4 & 163.16 \\
\hline No. of employees (end of year) & 307 & 261 & 259 & 234 & 233 \\
\hline No. of training hours per employee & 25.75 & 33.74 & 29.67 & 33.47 & 33.81 \\
\hline
\end{tabular}

Source: Titan Cementara Kosjerić (2011, 2012, 2013, 2014, 2015). Društveno odgovorno poslovanje $i$ održivi razvoj [Corporate social responsibility and sustainable development], Retrieved from: http://www.titan.rs/public/uploaded_files/Titan_CSR_Prikaz_SRP_web2.pdf; http://www.titan.rs/public/uploaded_files/2012_Titan_CSR_Report_SRB.pdf; http://www.titan.rs/public/uploaded_files/TITAN_2013_SRP_web.pdf; http://www.titan.rs/public/uploaded_files/TITAN_DOPIzvestaj_2014_SRB_web.pdf;

http://www.titan.rs/public/uploaded_files/TITAN_2015_Izvestaj_o_DOP_i_OR.pdf, Accessed on: 15th April $201 \overline{8}$.

\section{RESEARCH RESULTS AND DISCUSSION}

In dynamic and uncertain business conditions, Titan Cement Kosjerić implements its social responsibility policy, which, as one of the company's core values, lays out the way for business activities growth, but also contributes to improving the company's financial performances.

The coefficient of multiple correlations between the financial indicators is 0.792 , which means that there is a high degree of direct relationship between these three variables. Partial correlation coefficients show that there is a strong inverse relationship between the cement production and the increase of the Company's economic value (Pallant, 2013; the relationship is strong if the coefficient of correlation is greater than 0.5 ), while between the cement production and net profit there exists a strong direct dependence (the coefficient is 0.6).

The strategic effort of the Company's management to conserve natural resources is reflected in the reduction of the natural raw materials consumption, as well in the increase in the alternative raw materials share in the total consumption of materials. 
Table 2 Correlation of financial indicators

\begin{tabular}{lllrrr}
\hline & & & $\begin{array}{c}\text { Cement } \\
\text { production }\end{array}$ & $\begin{array}{c}\text { Increase of the } \\
\text { Company's } \\
\text { economic value }\end{array}$ & $\begin{array}{c}\text { Net } \\
\text { profit }\end{array}$ \\
\hline $\begin{array}{l}\text { Spearman's } \\
\text { rho }\end{array}$ & Cement & Correlation Coefficient & 1.000 & -.600 & .600 \\
& production & Sig. (2-tailed) & .285 & .285 \\
& Increase of the & Correlation Coefficient & -.600 & 5 & 5 \\
& Company's & Sig. (2-tailed) & .285 & 1.000 & -.800 \\
& economic value & $\mathrm{N}$ & 5 & .104 \\
& Net profit & Correlation Coefficient & .600 & 5 & 5 \\
& & Sig. (2-tailed) & .285 & -.800 & 1.000 \\
& & $\mathrm{~N}$ & 5 & .104 & 5 \\
\hline
\end{tabular}

Source: Authors' own presentation

As can be seen from Table 3, between the natural raw materials consumption and the secondary raw materials share in the consumption of materials there exists a negligible inverse relationship (the coefficient is -0.30). In the periods of declining natural raw materials quantities, the secondary raw material share of total consumption increased, apropos, the Company's management intensively worked on their substitution. In particular, the increase of the secondary raw materials share in total consumption of materials in 2014 led to an increase in the selected financial indicators - cement production, increase of the Company's economic value and net profit.

Table 3 Correlation between the natural raw materials consumption and the secondary raw materials share in the total consumption of materials

\begin{tabular}{|c|c|c|c|c|}
\hline & & & $\begin{array}{c}\text { Natural raw } \\
\text { materials } \\
\text { consumption }\end{array}$ & $\begin{array}{l}\text { Secondary } \\
\text { raw materials } \\
\text { share in the } \\
\text { consumption } \\
\text { of materials }\end{array}$ \\
\hline \multirow[t]{4}{*}{$\begin{array}{l}\text { Spearman's } \\
\text { rho }\end{array}$} & \multirow{2}{*}{$\begin{array}{l}\text { Natural raw } \\
\text { materials } \\
\text { consumption } \\
\end{array}$} & $\begin{array}{l}\text { Correlation Coefficient } \\
\text { Sig. (2-tailed) }\end{array}$ & 1.000 & $\begin{array}{r}-.300 \\
.624\end{array}$ \\
\hline & & $\mathrm{N}$ & 5 & 5 \\
\hline & \multirow{2}{*}{$\begin{array}{l}\text { Secondary raw } \\
\text { materials share in } \\
\text { the consumption of } \\
\text { materials }\end{array}$} & $\begin{array}{l}\text { Correlation Coefficient } \\
\text { Sig. (2-tailed) }\end{array}$ & $\begin{array}{r}-.300 \\
.624\end{array}$ & $\begin{array}{r}1.000 \\
.\end{array}$ \\
\hline & & $\mathrm{N}$ & 5 & 5 \\
\hline
\end{tabular}

Source: Authors' own presentation

In addition to raw materials, thermal and electric energy make basic resources for the cement and construction industry, which are highly energy-intensive. Whereas those operations can have a far-reaching impact on climate change, Table 4 shows the correlation between the indicators of harmful gases emissions.

When the effect of the produced cement quantity by years is removed, the partial correlation coefficients between the indicators of the harmful gases emissions have shown the following: 
1. There is a direct strong, almost perfect correlation (0.999) between the $\mathrm{CO}_{2}$ emission and the particulate matters total emission, as well as between $\mathrm{CO}_{2}$ emission and $\mathrm{NO}_{\mathrm{x}}$ total emission. Apropos, with the $\mathrm{CO}_{2}$ emissions reduction, the particulate matters total emission also decreases; as well as with the $\mathrm{CO}_{2}$ emission reduction reduces air emissions $\left(\mathrm{NO}_{\mathrm{x}}\right)$ produced during cement production also reduce. This directly confirms the internal emissions management system efficiency in the Company, through the adequate production processes management, the regular equipment maintenance, and the continuous emission levels monitoring on major broadcasters. In addition, the $\mathrm{CO}_{2}$ emission and recycled waste quantity are indirectly related, whereby this connection is of extremely low intensity $(-0.272)$.

2. There exists an almost perfect direct correlation (0.946) between the particulate matters total emission and $\mathrm{NO}_{\mathrm{x}}$ total emission. Apropos, in the whole observed period, air emissions are reduced.

3. There exists an inverse negligible relationship (-0.223) between the particulate matters total emission and the recycled waste quantity, which is logical since the recycled waste quantity is increasing from year to year and the particulate matters total emissions fall.

4. There is a negligible direct correlation between the $\mathrm{NO}_{\mathrm{x}}$ total emissions and the recycled waste quantity $(0.105)$.

Table 4 Correlation between the indicators of harmful gases emissions

\begin{tabular}{|c|c|c|c|c|c|c|}
\hline \multicolumn{3}{|c|}{ Control Variables } & $\begin{array}{c}\mathrm{CO}_{2} \\
\text { emission }\end{array}$ & $\begin{array}{l}\text { Particulate } \\
\text { matters } \\
\text { total } \\
\text { emission }\end{array}$ & $\begin{array}{l}\mathrm{NO}_{\mathrm{x}} \text { total } \\
\text { emission }\end{array}$ & $\begin{array}{l}\text { Recycled } \\
\text { waste } \\
\text { quantity }\end{array}$ \\
\hline \multirow{12}{*}{$\begin{array}{l}\text { Cement } \\
\text { production }\end{array}$} & $\mathrm{CO}_{2}$ emission & Correlation & 1.000 & .999 & .928 & -.272 \\
\hline & & $\begin{array}{l}\text { Significance } \\
\text { (2-tailed) }\end{array}$ & $\cdot$ & .033 & .242 & .824 \\
\hline & & df & 0 & 1 & 1 & 1 \\
\hline & Particulate & Correlation & .999 & 1.000 & .946 & -.223 \\
\hline & $\begin{array}{l}\text { matters total } \\
\text { emission }\end{array}$ & $\begin{array}{l}\text { Significance } \\
\text { (2-tailed) }\end{array}$ & .033 & - & .210 & .857 \\
\hline & & df & 1 & 0 & 1 & 1 \\
\hline & $\mathrm{NO}_{\mathrm{x}}$ total & Correlation & .928 & .946 & 1.000 & .105 \\
\hline & emission & $\begin{array}{l}\text { Significance } \\
\text { (2-tailed) }\end{array}$ & .242 & .210 & & .933 \\
\hline & & df & 1 & 1 & 0 & 1 \\
\hline & Recycled waste & Correlation & -.272 & -.223 & .105 & 1.000 \\
\hline & quantity & $\begin{array}{l}\text { Significance } \\
\text { (2-tailed) }\end{array}$ & .824 & .857 & .933 & \\
\hline & & df & 1 & 1 & 1 & 0 \\
\hline
\end{tabular}

Also, the correlation analysis has shown (Table 5) that between the cement production and recycled waste quantity there exists an inverse strong correlation $(-0.800)$. 
Table 5 Correlations between the cement production and the recycled waste quantity

\begin{tabular}{lllrr}
\hline & & \multicolumn{2}{c}{$\begin{array}{l}\text { Recycled } \\
\text { waste } \\
\text { quantity }\end{array}$} & \multicolumn{2}{c}{$\begin{array}{l}\text { Cement } \\
\text { production }\end{array}$} \\
\hline Spearman's rho & Recycled waste & Correlation Coefficient & 1.000 & -.800 \\
& quantity & Sig. (2-tailed) &. & .200 \\
& $\mathrm{~N}$ & 4 & 4 \\
\cline { 2 - 6 } & Cement production & Correlation Coefficient & -.800 & 1.000 \\
& Sig. (2-tailed) & .200 &. \\
& $\mathrm{~N}$ & 4 & 5 \\
\hline
\end{tabular}

Source: Authors' own presentation

None of the obtained correlation coefficients are statistically significant, primarily because they are calculated on the basis of a short period of time.

The improvement of the Company's social performances is largely determined by its financial performances and in particular by company's economic value. This statement is confirmed by the results of a correlation analysis between the Company's economic value and selected indicators of social performances (Table 6).

Table 6 Correlation analysis between the Company's economic value and the selected indicators of social performances

\begin{tabular}{|c|c|c|c|c|c|}
\hline & & & $\begin{array}{l}\text { Increase of } \\
\text { the } \\
\text { Company's } \\
\text { economic } \\
\text { value }\end{array}$ & $\begin{array}{c}\text { No. of } \\
\text { employees }\end{array}$ & $\begin{array}{c}\text { No. of } \\
\text { training } \\
\text { hours per } \\
\text { employee }\end{array}$ \\
\hline \multirow{9}{*}{$\begin{array}{l}\text { Spearman's } \\
\text { rho }\end{array}$} & \multirow{3}{*}{$\begin{array}{l}\text { Increase of the } \\
\text { Company's } \\
\text { economic value }\end{array}$} & Correlation Coefficient & 1.000 & $-1.000^{* *}$ & .700 \\
\hline & & Sig. (2-tailed) & . & . & .188 \\
\hline & & $\mathrm{N}$ & 5 & 5 & 5 \\
\hline & \multirow[t]{3}{*}{ No. of employees } & Correlation Coefficient & $-1.000^{* *}$ & 1.000 & -.700 \\
\hline & & Sig. (2-tailed) & . & . & .188 \\
\hline & & $\mathrm{N}$ & 5 & 5 & 5 \\
\hline & \multirow{3}{*}{$\begin{array}{l}\text { No. of training } \\
\text { hours per } \\
\text { employee }\end{array}$} & Correlation Coefficient & .700 & -.700 & 1.000 \\
\hline & & Sig. (2-tailed) & .188 & .188 & . \\
\hline & & $\mathrm{N}$ & 5 & 5 & 5 \\
\hline
\end{tabular}

**. Correlation is significant at the 0.01 level (2-tailed).

Source: Authors' own presentation

It could be noted that there is a perfect inverse relationship between the number of employees and the Company's economic value (Spearman rank correlation coefficient 1.000). Apropos, the reduction in the number of employees follows the reduction in the company's economic value. Between the Company's economic value and the number of training hours per employee there exists a direct relation (0.700). In other words, as the Company's economic value increases, the number of training hours per employee also 
increases, which confirms the company's efforts towards improving the competencies of employees.

In addition, it is noticeable that between the number of employees and the number of training hours per employee there exists an inverse relationship $(-0.700)$. The reason is that in the observed period the number of employees has been steadily decreasing, while the number of training hours per employee has registered a steady increase. This can be explained by the fact that the Company's management has focused more attention on additional training of existing employees.

\section{CONCLUSION}

Business activities that are carried out in Titan Cement Kosjerić include the process of ore extraction, crushing, grinding, mixing and baking of raw materials, cement grinding, packaging and distribution of the product. Due to the fact that these activities can make a potentially large environmental and social damage, the company's management activities are aimed at minimizing or eliminating environmental and social risks according to the business vision: "We strive to always achieve the business goals and create value in an ethical and socially responsible manner, making it less bad, striving to do better" (Titan Cementara Kosjerić, 2014, p. 9).

Titan Cement Kosjeric is an active promoter of the sustainable development concept. Recognizing the importance of inclusion in the sustainable development program for the Company's financial performance, and aware of the direct environmental impact of cement production, the Company's management committed to full responsibility in respecting of the sustainable development principles.

Consistent application of the sustainable development principles permeates the company's business that is directed towards the realization of the objectives in the field of corporate social responsibility until 2020. This statement is confirmed by the research results that provided the basis for making the following conclusions.

First, there is a high degree of interdependence between the total cement production, net profit and the increase of Company's economic value, as financial indicators of company's business performance.

Second, the continuous innovating of the production process by applying the best available technologies has contributed to reducing the natural raw materials consumption and increasing the secondary raw materials share in total consumption in the observed period.

Third, the reduction of the total $\mathrm{CO}_{2}$ emission arises due to the measures taken to increase the energy efficiency of the clinker production process, reducing the clinker share in cement and using alternative fuels or biomass. With the reduction of $\mathrm{CO}_{2}$ emission are also reduced the particulate matter total emissions and $\mathrm{NO}_{\mathrm{x}}$ total emission that occur during the production of cement. Among the particulate matter total emissions and $\mathrm{NO}_{\mathrm{x}}$ total emissions almost perfect direct correlation (0.946) is affirmed, which leads to the conclusion that in the whole observed period air emissions decreased. In addition, throughout the period the waste recycled quantity increased. All the above mentioned confirms the assumption that the Company made great efforts to reduce greenhouse gases emissions and more efficient packaging waste management in the observed period. 
Fourth, regarding the Company's social performances through indicators - the number of employees and number of training hours per employee, it was found that between a number of employees and the Company's economic value there exists a perfect inverse relationship; and that between the company's economic value and the number of training hours per employee there exists a direct relation $(0,700)$. Increasing the number of training hours per employee in the observed period, despite a constant reduction of the employees' number is explained by the predominant directionality of the Company's management to additional training of existing employees. It also confirms the Company's strategic commitment to improving the employees' quality and strengthening Company's social performances.

It could be concluded that the Company Titan Cement Kosjeric applies the good business practice that respects the basic sustainable development principles. Compliance with codes of ethics, continuous implementation of activities towards improving the employees competence and skills and continuous innovation of production processes by introducing technology that is less environmentally intensive contributing to the increasing of Company's economic value and encouraging positive changes in the Company's environmental and social performances.

\section{REFERENCES}

European Commission (1999). Commission Staff Working Paper on Sustainable industrial development, Retrieved from: http://ec.europa.eu/environment/archives/action-programme/pdf/sec991729_en.pdf, Accessed on: 15 April 2018.

Figge, F., Hahn, T., Schaltegger, S. \& Wagner, M. (2002). The sustainability balanced scorecard - Linking sustainability management to business strategy. Business Strategy and the Environment, 11 (5), 269-284.

Gligorijević, Ž. \& Bošković, G. (2013). Industrijski menadžment [Industrial Management]. Niš: Ekonomski fakultet.

Hemmelskamp, J. \& Leone, F. (2001). Do environmental taxes and standards induce innovation? In: Welfens, P.J.J. (ed.), Internalization of the economy and environmental policy options (301-325). Berlin: Springer.

Jovanović, S., Radukić, S. \& Petrović-Ranđelović, M. (2011). Teorijski i institucionalni okvir održivog razvoja [Theoretical and institutional framework of sustainable development]. Niš: Ekonomski fakultet Univerziteta u Nišu.

Kaplan, R. \& Norton, D. (1992). The balanced scorecard - Measures that drive performance. Harvard Business Review, January-February.

Magdalinović Kalinović, M. \& Radukić, S. (2016). Economic Effects and Regulatory Limits in Implementation of Environmental Taxes. Facta Universitatis, Series: Economics and Organization, 13 (4), 427-438.

Pallant, J. (2013). SPSS survival manual: A step by step guide to data analysis using IBM SPSS (4th ed.). Crows Nest, NSW: Allen \& Unwin.

Perović, D. \& Radukić, S. (2017). Comparative Analysis of Sustainable Development Components for the Republic of Serbia and Neighbouring Countries. Teme, 41 (3), 747-765.

Titan Cementara Kosjerić (2011). Društveno odgovorno poslovanje i održivi razvoj [Corporate social responsibility and sustainable development], Retrieved from: http://www.titan.rs/public/uploaded_files/Titan_CSR_Prikaz_SRP_ web2.pdf, Accessed on: 15 April 2018.

Titan Cementara Kosjerić (2012). Društveno odgovorno poslovanje i održivi razvoj [Corporate social responsibility and sustainable development], Retrieved from: http://www.titan.rs/public/uploaded_files/2012_Titan_CSR_ Report_SRB.pdf, Accessed on: 15 April 2018.

Titan Cementara Kosjerić (2013). Društveno odgovorno poslovanje i održivi razvoj [Corporate social responsibility and sustainable development], Retrieved from: http://www.titan.rs/public/uploaded_files/TITAN_2013_SRP_web.pdf, Accessed on: 15 April 2018.

Titan Cementara Kosjerić (2014). Društveno odgovorno poslovanje i održivi razvoj [Corporate social responsibility and sustainable development], Retrieved from: http://www.titan.rs/public/uploaded_files/TITAN_DOPIzvestaj_2014_ SRB_web.pdf, Accessed on: 15 April 2018.

Titan Cementara Kosjerić (2015). Društveno odgovorno poslovanje i održivi razvoj [Corporate social responsibility and sustainable development], Retrieved from: http://www.titan.rs/public/uploaded_files/TITAN_2015_ Izvestaj_o_DOP_i_OR.pdf, Accessed on: 15 April 2018. 
Titan Cementara Kosjerić (2018a). Retrieved from: http://www.titan.rs/home/page/1/Titan-Cementara-Kosjer, Accessed on: 15 April 2018.

Titan Cementara Kosjerić (2018b), Retrieved from: http://www.titan.rs/home/page/0/O-nama, Accessed on: 15 April 2018.

Titan Group (2018), Retrieved from: http://www.titan.gr/en/titan-group/, Accessed on: 15 April 2018.

World Business Council for Sustainable Development (2002). Toward sustainable cement industry: Summary report, Retrieved from: https://www.wbcsdcement.org/pdf/battelle/final_report8.pdf, Accessed on: 15 April 2018.

\section{MEĐUZAVISNOST IZMEĐU EKOLOŠKIH I SOCIJALNIH PERFORMANSI I EKONOMSKE VREDNOSTI KOMPANIJE: PRIMER TITAN CEMENTARE KOSJERIĆ}

Cilj ovog rada je da ispita odnos između ekoloških i socijalnih performansi i ekonomske vrednosti kompanije na primeru Titan cementare Kosjerić, kao i da doprinese jasnijem razumevanju značaja integracije principa održivog razvoja u poslovne strategije i procese. Istraživanje je sprovedeno korišćenjem podataka o odabranim finansijskim i nefinansijskim performansama kompanije iz Izveštaja o društveno odgovornom poslovanju i održivom razvoju za period od 2011. do 2015. godine. U cilju potvrđivanja polaznih hipoteza korišćeni su metod analize, metod sinteze i metod korelacione analize. Emprijski nalazi ovog istraživanja ukazuju da postoji visok stepen međuzavisnosti između ekoloških $i$ socijalnih performansi i ekonomske vrednosti kompanije, što je u skladu sa obavezivanjem kompanije na održivi razvoj i društveno odgovorno poslovanje. Glavni doprinos rada ogleda se u naglašavanju značaja realizacije društveno odgovorne prakse u kompanijama iz oblasti industrije cementa za unapređenje svih aspekata održivog poslovanja - finansijskog, ekološkog i socijalnog.

Ključne reči: održivi razvoj, ekološke i socijalne performanse, ekonomska vrednost kompanije, Titan cementara Kosjerić. 